\title{
Community perception of the real impacts of human-wildlife conflict in Laikipia, Kenya: capturing the relative significance of high-frequency, low-severity events
}

Alec G. Blair and Thomas C. Meredith

\begin{abstract}
Biodiversity conservation outside protected areas requires cooperation from affected communities, hence the extensive discussions of trade-offs in conservation, and of a so-called new conservation that addresses human relations with nature more fully. Human-wildlife conflict is one aspect of those relations, and as land use intensifies around protected areas the need to understand and manage its effects will only increase. Research on human-wildlife conflict often focuses on individual species but given that protecting wildlife requires protecting habitat, assessments of humanwildlife conflict should include subsidiary impacts that are associated with ecosystem conditions. Using a case study from Laikipia, Kenya, where conservation outside protected areas is critical, we analysed human-wildlife conflict from a household perspective, exploring the full range of impacts experienced by community members on Makurian Group Ranch. We addressed questions about four themes: (1) the relationship between experienced and reported humanwildlife conflict; (2) the results of a high-resolution assessment of experienced human-wildlife conflict; (3) the relative impact of high-frequency, low-severity conflict vs high-severity, low-frequency conflict; and (4) the effect of experienced conflict on receptivity to the conservation narrative. Our results show that high-frequency, low-severity conflict, which is often absent from reports and discussion in the literature, is a significant factor in shaping a community's perception of the cost-benefit ratio of conservation. Local, ongoing, high-resolution monitoring of humanwildlife conflict may facilitate more realistic and effective incorporation of the experienced impacts of human-wildlife conflict in conservation planning and management. Such monitoring could help to define locally appropriate tradeoffs in conservation and thereby improve conservation outcomes.
\end{abstract}

Keywords Biodiversity conservation, community development, ecotourism, human-wildlife conflict, Kenya, Laikipia, livestock depredation

\footnotetext{
Alec G. Blair (Corresponding author) and Thomas C. Meredith Department of Geography, McGill University, Montreal, Canada

E-mail alec.blair@mail.mcgill.ca

Received 24 April 2016. Revision requested 29 June 2016.

Accepted 29 September 2016. First published online 13 February 2017.
}

\section{Introduction}

T ivelihood diversification for pastoralists in Kenyan ran$\_$gelands has been increasing since the mid 1990s, in part because of the persistent vulnerability of livestock to drought, exacerbated by climate change (Homewood et al., 2012; Letai \& Lind, 2013). Community-based conservation initiatives have been embraced as a major diversification strategy: communally held lands are being designated as conservancies and taking on an increasingly important role in wildlife conservation, as well as providing livelihood opportunities for communities (Western et al., 2015). Many of these areas have experienced increases in wildlife populations and attracted international conservation and tourism attention but they are also home to human communities dependent on traditional livelihoods, living in material poverty but with high expectations for economic development.

Adams (2003) wrote 'the real work of re-imagining conservation for a post-colonial era is just beginning.' Although protected areas are essential to biodiversity conservation (Stolton et al., 2015) they are not always successful (Craigie et al., 2010) and they are not sufficient; as 'most biodiversity resides in human-modified landscapes' conservation requires 'far more space than the protected areas cover' (Western et al., 2015). The paradigm of conservation increasingly recognizes the role that human communities have in shaping ecosystems, and must have in protecting them, and the conservation dialogue has shifted to address essential trade-offs (i.e. the balance of costs and benefits amongst stakeholders; Leader-Williams et al., 2010). A socalled new conservation is proposed, entailing actions intended to 'improve or maintain good relations with nature' (Sandbrook, 2015). Achieving good relations with nature may be complex everywhere but is particularly so in biodiversity-rich environments where local stakeholders may still be negotiating post-colonial legacies and persistent inequality, poverty and/or political marginalization.

Kenya is one such region. It has iconic biodiversity resources, with the majority of its wildlife found outside protected areas, amongst rural populations (Western et al., 2009). Laikipia, a plateau in north-central Kenya, is a rare example of a site where, even without national parks or government game reserves, wildlife populations have increased (Kinnaird \& O’Brien, 2012). However, Laikipia is also an 
area with a complex colonial and post-colonial history that has shaped both the landscape (large private ranches and communally owned pastoral rangelands; Ulrich et al., 2012; Onyango, 2014) and the social dynamics (a rapidly increasing population, increasing livelihood expectations and lingering equity issues; Roden et al., 2016). The potential benefits to conservation science of learning to re-imagine conservation and maintain good relations with nature are perhaps nowhere greater than in Laikipia.

The support of local communities is recognized as being essential to protecting biodiversity (Barrow \& Fabricius, 2002; Western et al., 2015). It is both an instrumental necessity and a means to address obligations associated with social development expectations (Western \& Wright, 1994; Adams \& Hulme, 2001a; Kirby, 2014). Communities affected by wildlife cannot be asked to bear the costs of wildlife impacts without also receiving benefits (Adams \& Hulme, 2001a; Bowen-Jones, 2012; Ogada, 2015). Potential benefits are many, including protection of essential ecosystem goods and services and direct employment in conservation initiatives, but also including access to novel and potentially lucrative market-based livelihood activities linked to tourism (Leisher et al., 2013; Roe et al., 2014). However, consistent success in delivering net benefits to communities has been elusive (Hackel, 1999; Newmark \& Hough, 2000; Adams \& Hulme, 2001b; Hughes \& Flintan, 2001; Kiss, 2004; McShane \& Wells, 2004; Homewood et al., 2012).

The costs that offset benefits to communities are varied, but significant among them are human-wildlife conflicts, which can increase with conservation success (Jones et al., 2013; Khumalo \& Yung, 2015; Western et al., 2015). These include direct impacts, such as livestock depredation, human injury or fatality, crop-raiding and infrastructure damage (Thirgood et al., 2005), and indirect impacts, such as time lost to adjusting to wildlife (Lamarque et al., 2009; Barua et al., 2013). The costs of human-wildlife conflict add significant stresses to household economies (Thirgood et al., 2005; Holmern et al., 2007). Local tolerance of the impacts of human-wildlife conflict has been shown to decrease anti-conservation behaviour, such as retaliatory killing (Western \& Waithaka, 2005). This can be influenced by social conditions (Romañach et al., 2007; Khumalo \& Yung, 2015; Dickman \& Hazzah, 2016) and by the success of conservation projects in delivering real or expected benefits (Salerno et al., 2016). However, as it is the perceived costbenefit ratio that will determine the acceptance of wildlife, detailed assessments of the full range of experienced conflicts are essential. To date, the focus of human-wildlife conflict research has been predominantly species specific (e.g. Hemson et al., 2009; Frank, 2011; Babrgir et al., 2017) and centred on predators and charismatic megafauna (Redpath et al., 2015), but these species depend on distinctive habitat conditions, and current standard conflict assessments focused only on key species will miss potential contingent conflict impacts arising from the full assemblage of species, and ecosystem conditions, associated with the conservation habitat. Calls for a broader base of evidence in conservation decision making, with more weight allocated to local and indigenous knowledge (Adams \& Sandbrook, 2013), suggest that local and indigenous perceptions of the costs and benefits of living with wildlife should be addressed. This will require sitespecific high-resolution studies that explore the full array of human-wildlife conflict. An accurate understanding of the local perception of the costs of conservation may be critical to mediating conservation trade-offs and, therefore, to the success and sustainability of conservation initiatives.

Here we attempt to capture local perceptions of humanwildlife conflict in the Mukogodo region of Laikipia, to determine what role it may play in local conservation dynamics. We examine four questions: (1) What is the relationship between the experienced impact of human-wildlife conflict and the official record that is used to shape conservation policy? (2) What does a high-resolution assessment reveal about the experienced impact of human-wildlife conflict? (3) What is the relative net impact of high-frequency, low-severity conflict vs high-severity, low-frequency conflict in shaping individuals' assessments of the significance of human-wildlife conflict? (4) What is the effect of experiences of human-wildlife conflict on individuals' receptivity to the wildlife conservation narrative? The answers to these questions will help determine the extent to which humanwildlife conflict influences local acceptance of biodiversity conservation programmes.

\section{Study area}

Laikipia $\left(9,700 \mathrm{~km}^{2}\right)$ borders the Aberdares Mountains to the west and Mount Kenya to the south-east. As a result of high spatial variability in elevation $(1,600-2400 \mathrm{~m})$ and annual rainfall (400-1,200 mm), Laikipia's ecological characteristics and vegetation range from montane forests to savannah grasslands and semi-arid pastoral rangeland (Butynski \& de Jong, 2015). This results in a wide variety of land use, including large- and small-scale agriculture, private commercial ranches, pastoralist group ranches, and forest reserves. The social history of the area is complex, with historical intertribal conflicts, major colonial impacts, and ongoing development challenges (Letai \& Lind, 2013). The area supports rich biodiversity, which persists partly as a result of centuries of semi-nomadic pastoralist land use across soft-boundary rangeland ecosystems (Reid, 2013), and large parcels of open rangeland that have avoided subdivision. Beginning in the 1980 os many large private ranches created private game reserves for luxury-market ecotourism. The Laikipia Wildlife Forum was established in 1992 to 'conserve Laikipia's wildlife and ecosystem integrity and improve the lives of its people by bringing its societies together to 


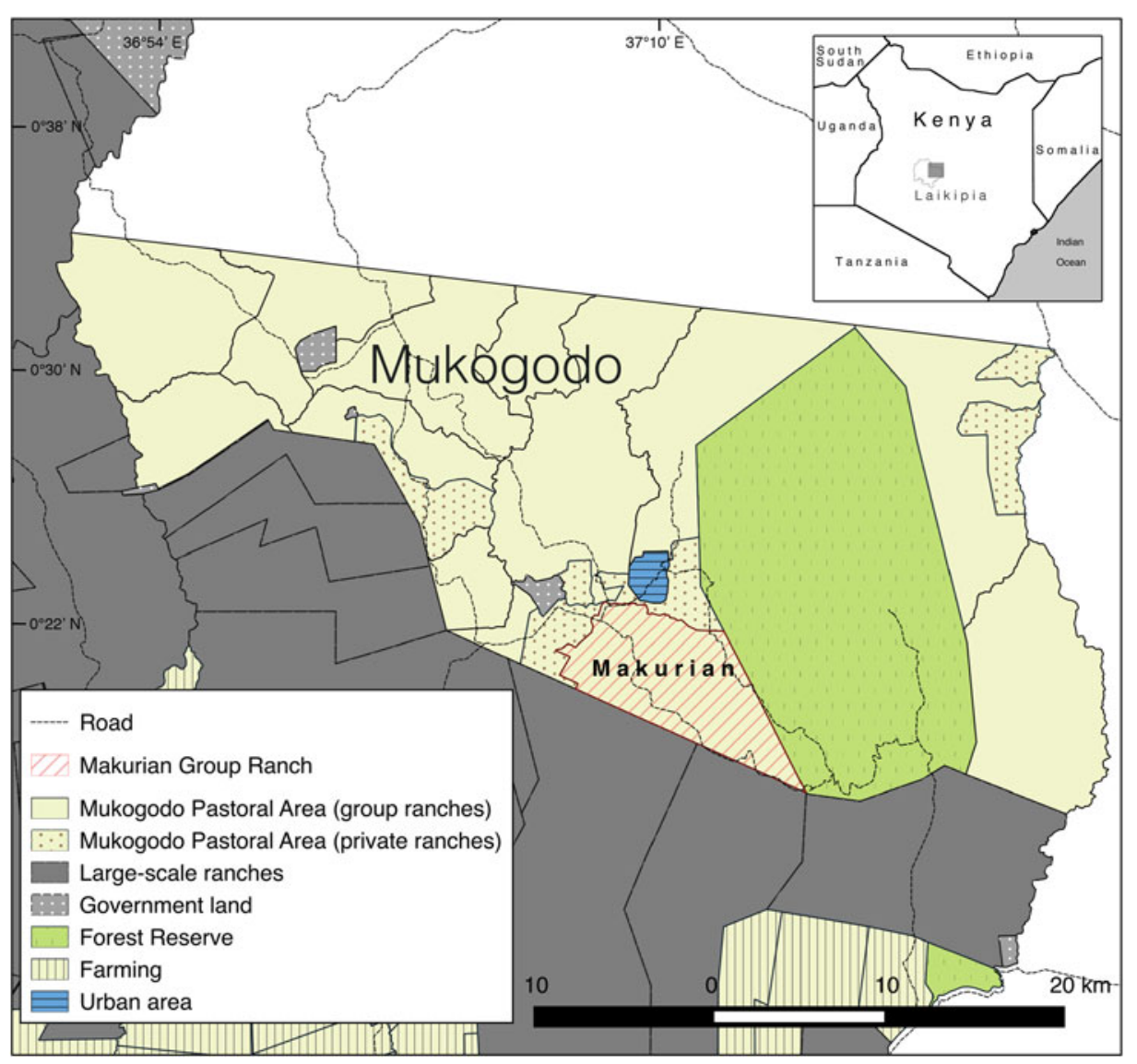

FIG. 1 Location of Makurian Group Ranch in the Mukogodo region of Laikipia, Kenya. conserve and sustainably use the natural resources on which they depend' (LWF, 2016). The Forum has become the local hub for funding and international support. Tourism is a growing industry in Laikipia, with 43 active tourism facilities as of 2013 , and a $1,400 \%$ increase in visitor numbers during 1996-2009 (LWF, 2013).

To study the functional impact of human-wildlife conflict on the local community we selected a site where conservation and development agendas coexist. Mukogodo, an area of $1,103 \mathrm{~km}^{2}$ in the north-eastern corner of Laikipia, has 13 communally held group ranches, in a semi-arid landscape, and a population of c. 25,000 people in c. 5,000 households (Kenya National Bureau of Statistics, 2010). The people of the area identify as Maasai and have traditionally engaged in a mixture of hunting, gathering, beekeeping and semi-nomadic pastoralism. They have embraced community-based conservation: all 13 of the group ranches are now involved in ecotourism, and all have designated land for wildlife conservation.

Our high-resolution assessment focused on one group ranch, Makurian (6,816 ha), selected because it had made an ambitious commitment to conservation but its core livelihood base was (and is) in pastoralism and opportunistic cultivation. The group ranch has $>1,300$ registered members, with an associated population of c. 5,000, but limited livelihood opportunities mean that $<2$,000 reside on the ranch. Makurian borders private, fenced, large-scale ranches to the south, other group ranches and small private Maasai-owned ranches to the north and west, and the Mukogodo Forest Reserve (30,100 ha) to the east, of which it has customary control of $25 \%$ (Fig. 1). Three distinct neighbourhoods exist, distinguished by gradients in biophysical attributes as the elevation drops from the forest in the east to the arid rangeland in the west. Homesteads are dispersed evenly throughout. Only the area bordering the forest has potential for reliable small-scale agriculture.

Makurian began its engagement with formal conservation in 1999 with a proposal for the Oreteti Conservancy, following the prominent example of the neighbouring Il Ngwesi Group Ranch. In 2004 it established a 2,043 ha conservation area within its section of the Mukogodo Forest but it has yet to realize reliable economic benefits from the project. The designated conservation areas are maintained and wildlife protection is still a formal commitment of the group ranch. Although wildlife densities have increased as a result of conservation commitments, pastoralism and some cultivation remain the main livelihoods, both of which are vulnerable to human-wildlife conflict. The local perception of the interaction of conservation and livelihood pursuits will shape land use decisions and conservation planning for the future. Accurate assessments of the impacts of human-wildlife conflict will therefore be important. 


\section{Methods}

\section{Data collection}

To address the research questions, studies of human-wildlife conflict were conducted at three scales: (1) the official general overview as reported by Kenya Wildlife Service, (2) a regional survey covering multiple Mukogodo communities, and (3) detailed key informant interviews conducted on one ranch. As noted, the Mukogodo region was selected for study because of coexisting conservation and development agendas and Makurian was selected for the highresolution assessment because of its espoused commitment to conservation and its livelihood and land use attributes.

To assess the relationship between community experiences of human-wildlife conflict and official records, monthly data for 2006 and 2007 were first collected from existing records in the regional offices of Kenya Wildlife Service. Preliminary data on experienced human-wildlife conflict in Mukogodo were then collected in July and August 2007 in a survey of 90 randomly selected community representatives across 11 group ranches in Mukogodo. Thirty surveys were conducted at randomly selected homesteads, and 60 were conducted at local markets in Mukogodo. Structured surveys gathered information about species involved in conflict, as well as details of respondents' most recent incidents. This provided a general overview of major forms of conflict experienced on the group ranches.

This overview was followed by interviews with key informants, which provided high-resolution data on conflict experiences. Interviews were conducted in February 2013 in Makurian. A preliminary survey identified 242 households in the three neighbourhoods; 10 were selected at random from each neighbourhood (R1-R3o) to capture spatial heterogeneity. Semi-structured interviews were conducted with the most senior member of the household available. Respondents were asked to describe the full range of conflict they had experienced in the last year, including the species involved, the nature and frequency of the conflicts, and specific losses. Follow-up questions focused on conservation, livelihoods and challenges. Additional key-informant interviews with local community leaders, and NGO and government representatives were conducted during 20072014. Thirty interviews were considered to be sufficient as they unequivocally demonstrated the inconsistency between experienced and officially recorded impacts and provided a clear picture of local conflict.

\section{Definitions and terminology}

Human-wildlife conflict, although a contested term (Redpath et al., 2015), denotes damage to property, limb or life, or disturbance of the rights of individuals or groups that are directly attributable to the actions or presence of wild animals. Accordingly, we asked respondents to describe their experiences and identify what they perceived as conflict attributable to the presence of wildlife. In many cases this involved events in which losses were not quantifiable but where the threat of loss or damage was perceived as immediate and significant, and some disturbance of rights resulted; for example, time and effort lost to protecting assets from damage was counted as a cost of conflict, even where no material damage resulted. The array of damages and disturbances reported were grouped into categories of conflict (Table 2). The term 'point of conflict' is used to denote each cell in an interaction matrix listing all reported species against all reported categories of conflict (Table 3).

In a few cases where vernacular language used by respondents prevented unambiguous identification to species level, allied or similar species were aggregated into groups (e.g. birds that caused livestock damage ('hawk' and 'eagle') were grouped as 'birds of prey'; birds that fed on crops ('hornbill', 'finch' and 'bird') were grouped as 'small birds'; jackals and foxes were grouped as 'small canines', and spotted and striped hyaenas, Crocuta crocuta and Hyaena hyaena, respectively, were recorded as 'hyaena'; vultures, rats and insect groups were recorded in the respondents' language. For these groups the Latin names of species are not used in the discussion.

\section{Results}

\section{Official and preliminary data on conflict experiences}

Kenya Wildlife Service recorded few incidents of humanwildlife conflict in Mukogodo during February-July 2007 (the 6 months preceding the survey): 11 incidents were recorded in the local headquarters, and none were recorded in the Laikipia regional office.

By contrast, all of the respondents in the 2007 Mukogodo sample reported experiencing human-wildlife conflict. Regarding species involved in conflict, elephants Loxodonta africana were the most commonly reported (94.4\%; Table 1), followed by hyaenas (88.9\%), baboons Papio spp. (64.4\%) and leopards Panthera pardus (62.2\%). In respondents' most recent conflict experience, the most common species involved were hyaenas (34.4\%) and elephants (32.2\%), followed by baboons (10.0\%). Recent incidents were dominated by livestock damage (70.0\%), followed by infrastructure damage (13.3\%), human fatalities or injuries (7.8\%), and crop damage (5.6\%), and were reported as having occurred within the past week (47.8\%), within the previous month $(77.8 \%)$ or within the previous 6 months $(85.6 \%)$.

For the same 6-month period significantly fewer incidents were recorded by Kenya Wildlife Service, which 
TABLE 1 Species most commonly reported to come into conflict with people in Mukogodo Division, Laikipia (2007) and Makurian Group Ranch (2013), Kenya (Fig. 1).

\begin{tabular}{|c|c|c|c|c|}
\hline \multirow[t]{2}{*}{ Species } & \multicolumn{2}{|c|}{ Mukogodo Division (2007) } & \multicolumn{2}{|c|}{ Makurian Group Ranch (2013) } \\
\hline & $\%$ households $(n=90)$ & Rank & $\%$ households $(\mathrm{n}=30)$ & Rank \\
\hline Elephant Loxodonta africana & 94.4 & 1 & 96.7 & 1 \\
\hline Hyaena Crocuta crocuta \& Hyaena hyaena & 88.9 & 2 & 96.7 & 1 \\
\hline Baboon Papio spp. & 64.4 & 3 & 13.3 & 8 \\
\hline Leopard Panthera pardus & 62.2 & 4 & 63.3 & 3 \\
\hline African wild $\operatorname{dog}$ Lycaon pictus & 47.8 & 5 & 36.7 & 6 \\
\hline Lion Panthera leo & 40.0 & 6 & 23.3 & 7 \\
\hline Buffalo Syncerus caffer & 32.2 & 7 & 3.3 & 24 \\
\hline Cheetah Acinonyx jubatus & 28.9 & 8 & 13.3 & 8 \\
\hline Monkeys & 21.1 & 9 & 10.0 & 11 \\
\hline Small canines & 10.0 & 10 & 50.0 & 4 \\
\hline Birds of prey & & & 50.0 & 4 \\
\hline Caterpillars & & & 13.3 & 8 \\
\hline
\end{tabular}

TABLE 2 Categories of human-wildlife conflict experienced by households $(\mathrm{n}=30)$ in Makurian Group Ranch (Fig. 1).

\begin{tabular}{|c|c|c|}
\hline $\begin{array}{l}\text { Nature of } \\
\text { conflict }\end{array}$ & Definition & $\begin{array}{l}\text { No. of households } \\
(\%)\end{array}$ \\
\hline $\begin{array}{l}\text { Livestock } \\
\text { damage }\end{array}$ & The loss of, or immediate threat to, cows, goats, sheep, chickens \& donkeys & $30(100)$ \\
\hline Tree damage & $\begin{array}{l}\text { Destruction or damage to trees (exclusively by elephants), which provide multiple functions to the } \\
\text { community, such as meeting areas, and shaded areas that function as an extension to the house }\end{array}$ & $19(63.3)$ \\
\hline Crop damage & $\begin{array}{l}\text { The loss or immediate threat of loss to agricultural crops, most commonly to small ( } 0.10-2 \mathrm{ha}) \\
\text { plots of beans, maize, potatoes or cabbage }\end{array}$ & $16(53.3)$ \\
\hline $\begin{array}{l}\text { Threats to } \\
\text { people }\end{array}$ & Death, injury or immediate threat to members of the household & $9(30)$ \\
\hline $\begin{array}{l}\text { Property } \\
\text { damage }\end{array}$ & $\begin{array}{l}\text { Damage or immediate threat to household property or shared communal property, such as } \\
\text { fences, houses, dams \& water pipes }\end{array}$ & $6(20)$ \\
\hline $\begin{array}{l}\text { Disease } \\
\quad \text { transmission }\end{array}$ & The transfer of disease to livestock or people & $5(16.7)$ \\
\hline $\begin{array}{l}\text { Limitations of } \\
\text { access }\end{array}$ & $\begin{array}{l}\text { The presence of wildlife limiting the activity or movement of community members; e.g. barriers to } \\
\text { children walking to school, or livestock accessing water }\end{array}$ & $3(10)$ \\
\hline Other & $\begin{array}{l}\text { Includes five cases (in four households): two reports of elephants introducing cactus (presumably } \\
\text { through depositing of seeds in faeces), two of locusts destroying pasture, \& one of noise dis- } \\
\text { turbance caused by hyaenas at night }\end{array}$ & $4(13.3)$ \\
\hline
\end{tabular}

influences policy and management practice. In a 2007 interview a senior warden in Laikipia stated that 'chances are slim of conflict in [Mukogodo], as the basic problem is farming and elephants, and there is no farming up there. . livestock depredation is very rare, very uncommon' and that, for the Maasai, 'a one-off [livestock depredation incident] is the normal way of life'. This contrasts with experiences reported by members of the local community.

\section{Local people's perceptions of conflict in Makurian}

Species in conflict Respondents in Makurian identified 31 species involved in human-wildlife conflict, which were aggregated into 26 groups for analysis (Table 3). Each household reported 2-12 species (mean $=5.73 \pm \mathrm{SD}_{3.13}$, median $=5$, interquartile range $=4.25$ ). Elephants and hyaenas were almost universally reported to be problematic, with both reported by $96.7 \%$ of households. These were followed by leopards $(63.3 \%)$, small canines (50.0\%) and birds of prey (50.0\%). The reduced geographical scope of the 2013 data (to a single group ranch, from 11 in 2007) accounts for the reduction in conflict with baboons and buffalo Syncerus caffer, and demonstrates the heterogeneity of wildlife distribution across the region (Table 1 ).

Nature of conflict Reported conflicts were categorized based on the nature of the adverse effects, considering together both realized (meaning material loss or damage) and immediate threats (meaning interactions 
TABLE 3 Interaction matrix of points of conflict reported by 30 households on Makurian Group Ranch in Kenya (Fig. 1), in descending order of priority. Data are presence/absence and therefore do not indicate the extent of the damage caused but the number of times each species was cited.

\begin{tabular}{|c|c|c|c|c|c|c|c|c|c|}
\hline \multirow[b]{2}{*}{ Species } & \multicolumn{8}{|c|}{ Nature of conflict } & \multirow[b]{2}{*}{ Total } \\
\hline & $\begin{array}{l}\text { Livestock } \\
\text { damage }\end{array}$ & $\begin{array}{l}\text { Crop } \\
\text { damage }\end{array}$ & $\begin{array}{l}\text { Tree } \\
\text { damage }\end{array}$ & $\begin{array}{l}\text { Injury/threat } \\
\text { to people }\end{array}$ & Disease & $\begin{array}{l}\text { Property } \\
\text { damage }\end{array}$ & Access & Other & \\
\hline Elephant & 6 & 14 & 19 & 9 & & 4 & 3 & 2 & 57 \\
\hline Hyaena & 29 & & & & & & & 1 & 30 \\
\hline Leopard & 19 & & & & & & & & 19 \\
\hline Small canines & 15 & & & & & & & & 15 \\
\hline Birds of prey & 15 & & & & & & & & 15 \\
\hline $\begin{array}{l}\text { African wild } \\
\text { dog }\end{array}$ & 11 & & & & & & & & 11 \\
\hline Lion & 7 & & & 3 & & & & & 10 \\
\hline Vulture & 3 & & & 2 & & & & & 5 \\
\hline Rat & & 2 & & & 1 & 2 & & & 5 \\
\hline Cheetah & 4 & & & & & & & & 4 \\
\hline Caterpillar & & 4 & & & & & & & 4 \\
\hline Baboon & 4 & & & & & & & & 4 \\
\hline Locust & & 1 & & & & & & 2 & 3 \\
\hline Small birds & & 3 & & & & & & & 3 \\
\hline Cutworm & & 3 & & & & & & & 3 \\
\hline Aphid & & 3 & & & & & & & 3 \\
\hline Monkey & & 3 & & & & & & & 3 \\
\hline Mosquito & & & & & 2 & & & & 2 \\
\hline $\begin{array}{l}\text { Tsetse fly } \\
\quad \text { Glossina spp. }\end{array}$ & & & & & 2 & & & & 2 \\
\hline Tick & & & & & 2 & & & & 2 \\
\hline Buffalo & 1 & & & 1 & & & & & 2 \\
\hline Weevil & & 2 & & & & & & & 2 \\
\hline Termite & & & & & & 2 & & & 2 \\
\hline $\begin{array}{l}\text { Porcupine } \\
\quad \text { Hystrix cristata }\end{array}$ & & 2 & & & & & & & 2 \\
\hline Housefly & & & & & 1 & & & & 1 \\
\hline Grasshopper & & 1 & & & & & & & 1 \\
\hline Total & 114 & 38 & 19 & 15 & 8 & 8 & 3 & 5 & 210 \\
\hline
\end{tabular}

that required protective intervention by the respondent) (Table 2). The most uniformly reported conflict was livestock damage (100\%), followed by damage to trees $(63.3 \%)$, and crop damage $(53.3 \%)$. Threats to people, property damage, disease transmission and limitations to access were reported by 30.0, 20.0, 16.7 and $10.0 \%$ of respondents, respectively.

Range of conflict In total 210 points of human-wildlife conflict were reported in interviews with 30 households, with 39 distinct points of conflict (Table 3 ). The most common conflict, damage to livestock by hyaenas, was reported almost uniformly, in $96.7 \%$ of households. Four other conflicts were reported by at least $50 \%$ of respondents: livestock damage by leopards, destruction of trees by elephants, damage to livestock by birds of prey, and damage to livestock by small canines. The points of conflict indicate precisely where specific groups of wildlife are imposing specific costs on households in Makurian. Elephants were cited in the widest range of conflicts; they were identified in seven of the eight categories of conflict and were the only species named in two of those categories: damage to trees and limitation to access. Six other species (hyaena, lion Panthera leo, vulture, rat, locust and buffalo) were named in more than one type of conflict, with the remaining 19 named in only one. Considering the species cited for each type of conflict, damage to livestock had the most species involved (11), followed by damage to crops (11), disease transmission (5), threats to people (4), damage to property (3), damage to trees (1) and limitations to access (1). There were 3-17 points of conflict per household (mean $=7 \pm$ SD 3.95, median $=6$, interquartile range $=6$ ). Although some of the categories of conflict may be regarded as problems with pests rather than wildlife, their inclusion is mandated by the focus on conflict linked to habitat conditions and defined by respondents' perceptions. 
TABLE 4 Reported frequencies for the 10 most common points of conflict experienced by households $(\mathrm{n}=30)$ on Makurian Group Ranch, Kenya (Fig. 1).

\begin{tabular}{|c|c|c|c|c|c|c|c|}
\hline \multirow[b]{2}{*}{ Points of conflict } & \multirow[b]{2}{*}{ Total no. of reports } & \multicolumn{6}{|c|}{ Frequency of conflict, \% (no. of reports) } \\
\hline & & Daily & Weekly & Monthly & Semiannual & Annual & Unknown \\
\hline Hyaena/livestock & 29 & $37.93(11)$ & $24.14(7)$ & $13.79(4)$ & 0 & $10.34(3)$ & $13.79(4)$ \\
\hline Leopard/livestock & 19 & 0 & $26.32(5)$ & $36.84(7)$ & $15.79(3)$ & $21.05(4)$ & 0 \\
\hline Elephant/trees & 19 & $42.11(8)$ & $5.26(1)$ & $15.79(3)$ & 0 & $5.26(1)$ & $31.58(6)$ \\
\hline Birds of prey/livestock & 15 & $73.33(11)$ & $20.00(3)$ & $6.67(1)$ & 0 & 0 & 0 \\
\hline Small canine/livestock & 15 & $46.67(7)$ & $40.00(6)$ & 0 & 0 & 0 & $13.33(2)$ \\
\hline Elephant/crops & 14 & $35.71(5)$ & 0 & $21.43(3)$ & $7.14(1)$ & $14.28(2)$ & $21.43(3)$ \\
\hline Wild dog/livestock & 11 & 0 & $36.36(4)$ & 0 & 0 & $63.64(7)$ & 0 \\
\hline Elephant/people & 9 & 0 & 0 & 0 & 0 & $44.44(4)$ & $55.56(5)$ \\
\hline Lion/livestock & 7 & 0 & 0 & 0 & 0 & $100.00(7)$ & 0 \\
\hline Elephant/livestock & 6 & 0 & 0 & 0 & 0 & $16.67(1)$ & $83.33(5)$ \\
\hline All points of conflict & 210 & $36.67(77)$ & $13.33(28)$ & $10.48(22)$ & $3.33(7)$ & $18.10(38)$ & $18.10(38)$ \\
\hline
\end{tabular}

Frequency of conflict Most households reported experiencing some form of conflict every day $(76.6 \%)$, $13.3 \%$ reported experiencing it weekly and 10\% monthly; no households reported that they did not experience any conflict. The 210 reported points of conflict demonstrate the range of perceptions and experiences (Table 4): $36.66 \%$ of conflicts were reported to occur on a daily basis, $13.33 \%$ weekly, $10.48 \%$ monthly, $3.33 \%$ semiannually, and $18.10 \%$ annually; $18.10 \%$ were of unspecified frequency. Over $60 \%$ of households reported experiencing threats from hyaenas daily or weekly. Damage by birds, although reported by fewer households overall, was reported as occurring frequently by those affected. Damage to livestock by canines is also notable for its consistency and frequency, with $>85 \%$ of households affected reporting daily or weekly events. Depredation of livestock by lions, and threats to people by elephants, although often discussed in the literature, were reported to occur infrequently, and no deaths or injuries to people were reported.

Household losses to conflict Data on the specific losses incurred by each household over the last year were used to determine the relative severity of impacts on livelihoods. Livestock losses and damage to crops, trees or infrastructure were the most significant forms reported. Livestock losses were the most common, with major losses of cattle, donkeys, sheep and goats (Table 5), as well as losses of chickens, dogs and cats. Based on mean local sale prices of KSh 30,150 for cows and KSh 3,475 for sheep/goats (LWF, 2013), the mean losses incurred annually per household were KSh 17,788 and KSh 41,943, respectively. Ten households reported specific crop damage in the previous year, all citing one or more of the following crops: beans, maize, potatoes and cabbage. Nine of the 10 reported that the entire crop was destroyed. As most crops are cultivated for subsistence use, and replacement values vary considerably by season, a cash value cannot be
TABLE 5 Summary of livestock losses in the previous year reported by 29 households in Makurian Group Ranch (Fig. 1) in 2013.

\begin{tabular}{llll}
\hline & Cows lost & Sheep/goats lost & Donkeys lost \\
\hline Mean \pm SD & $0.59 \pm 1.27$ & $12.07 \pm 11.99$ & $0.45 \pm 0.91$ \\
Median & 0 & 9 & 0 \\
Interquartile range & 0.5 & 11 & 0.5 \\
$\begin{array}{c}\text { No. of households } \\
\text { reporting losses }\end{array}$ & 7 & 28 & 7 \\
$\begin{array}{l}\text { No. of households } \\
\quad \text { reporting no }\end{array}$ & 22 & 1 & 22 \\
$\quad$ losses & & & \\
\hline
\end{tabular}

readily assigned. However, the losses represent significant costs. Nine households reported damage to trees by elephants, and seven reported damage to fences.

\section{Narrative responses}

Open-ended discussion with respondents about possible problems arising from the development of conservation initiatives in Makurian revealed that concerns about humanwildlife conflict were common, with $48 \%$ anticipating the problem would increase in the future. Anticipated problems included concerns about increasing wildlife density in the conservation area causing conflict on surrounding land:

There will be more problems... .between humans and wildlife because most conservancies aren't fenced. (R-5)

There will be increased human-wildlife conflict, especially with neighbours of the conservancy, for instance, cows attacked by lions. (R-7)

If wild animals are not fenced, there will be more human-wildlife conflict. (R-26)

Given the opportunity to raise questions or concerns about increases in wildlife, seven respondents questioned the motivations behind conservation: 
What is our benefit if wild animals are kept in our area? What will protect our livestock if wild animals increase in our area? (R-27)

Why are [wild animals] kept and yet they are interfering with our livestock? Where will [we] live when [wild animals] are brought in a large number? (R-26)

Why are wild animals staying here, and yet [they] can be conserved in game reserves or parks? (R-23)

Why are wild animals being conserved if they are destroying our environment and livestock? (R-21)

Why are wild animals increased in our area, and yet they cause a lot of damages and there is no compensation? (R-29)

Four respondents made distinctly negative comments about wildlife and conservation, including:

Wildlife are not good neighbours because we do not benefit from them. (R-3)

Wild animals are our enemies and should leave the community to increase pastures. (R-4)

A single respondent was positive, stating that it is

better if wildlife presence [is] increased, to increase income from tourism. (R-9)

Five respondents had larger questions, focusing on mitigation and management, such as:

[What are] ways of preventing wild animals [from causing conflict]? (R-2)

In what way can the community conservancies partner with nearby ranches/settlers and the international community? (R-25)

Why are wild animals not fenced to prevent insecurity? Why is there no compensation for livestock being killed by wild animals? (R-22)

One community leader described high levels of damage caused by wildlife, and reported that inaction by Kenya Wildlife Service resulted in frequent retaliatory poisoning of carnivores. Engagement with tourism was cited as an opportunity to stop retaliatory killings, but it had thus far failed to provide the necessary income. Thus the community was engaged in conservation and was anticipating an increase in damage caused by wildlife but was left without any means to provide compensation to victims of conflict. Concerns arose about the sustainability of community support for conservation in the event that monetary returns from tourism were not forthcoming.

\section{Discussion}

Addressing the research questions, we found that (1) official recorded levels of human-wildlife conflict considerably underrepresent the experience reported within the study community; (2) the array of points of conflict between people and wildlife is extensive, with species and interactions that are generally not discussed in conflict assessments playing a significant role in this area; (3) high-frequency, lowseverity human-wildlife conflict may have a higher material impact on livelihoods and well-being than high-severity, low-frequency events, although anxiety about severe but improbable events may have a perceptual impact beyond their material importance; and (4) the impacts of conflict are perceived as real costs within households, and this concern has shaped people's perception of the conservation narrative. These findings have implications for how human-wildlife conflict is monitored and reported at the local level and, more importantly, for understanding how it is experienced and perceived by those who live amongst wildlife and within conservation landscapes.

Regarding the first research question, at least in this case, existing literature and official documentation of conflict do not reflect either the intensity or the nature of the full range of conflicts between wildlife and households. Allowing respondents to define the scope of wildlife impacts has provided a clearer understanding of local points of tension, and has shown local variations, as demonstrated by differences in conflict trends between Makurian and the broader regional scale of Mukogodo or Laikipia. For example, conflicts arising from damage caused by baboons (prominent in wider Mukogodo), or crop-raiding by elephants (prominent at the Laikipia scale), are mild or absent in Makurian. Mitigation measures that focus principally on issues defined at the regional scale will fail to address prime concerns at the local level.

Regarding the second question, the array of reported points of conflict was extensive and varied. Damage to livestock was reported universally by Makurian respondents and this was dominated by conflict with hyaenas, which was reported by $97 \%$ of the sample, with $62 \%$ reporting experiencing such conflict at a high frequency (daily or weekly). For those households affected, depredation by birds of prey and small canines was also reported at a high frequency (93 and 87\%, respectively). In contrast, depredation by lions, a commonly cited source of conflict in the literature (Packer et al., 2005; Hemson et al., 2009; Frank, 2011; Hazzah et al., 2014), was cited by only $23 \%$ and was consistently reported as occurring at low frequency (annually). Sheep and goats are the most likely domestic animals to be lost to human-wildlife conflict, with losses reported by $97 \%$ of households (compared to $24 \%$ reporting loss of cattle, and $24 \%$ loss of donkeys). This form of conflict is experienced at a high frequency and, although the damage from any single incident may not be severe, the cumulative impact is significant: the economic cost of losses of sheep and goats was more than double the cost of cattle losses. Considering cumulative impacts, the high frequency makes this category of conflict a significant factor both for livelihoods and for shaping the local perception of human-wildlife conflict.

The next most cited causes of conflict were damage to trees $(63 \%)$, damage to crops (53\%) and threats to people $(30 \%)$, with elephants cited as the cause in 100, 37 and $60 \%$ of these points of conflict, respectively. All respondents cited elephants as a major cause of conflict. Damage to trees was reported as a daily occurrence by $47 \%$ of those affected, 
whereas threats to people were reported to occur infrequently. Both high-severity, low-frequency and low-severity, high-frequency conflict were important to respondents, yet only high-severity impacts are recorded by Kenya Wildlife Service.

On the third question, the overall experience reported by the Makurian community demonstrates both the pervasiveness and variability of conflict. Perception of conflict does not always correlate directly to tangible losses and can be distorted by rare severe events or by hearsay (Naughton-Treves \& Treves, 2005). This may account for the skewed perception of threats to people from elephants despite there having been no attacks in the year before data collection: even if the quantified risk is relatively low the perception of threat is always present, a factor that is not easily captured in measurements of conflict. Highseverity conflict, such as attacks on people, are well documented in the literature, and their effects on perceptions, sense of security and energy expended on vigilance (Khumalo \& Yung, 2015) are likely to have negative impacts on community support for conservation.

Previous studies in Laikipia have found that tolerance for hyaenas is lower than for other predator species, despite lower attributed measurable costs (Frank et al., 2005). The real costs of high-frequency, low-severity conflicts can be challenging to quantify and may be of low financial significance, but they present daily pressures that affect people's quality of life and their perceptions of wildlife and conservation.

On the final question, it is clear from the interviews that human-wildlife conflict and the lack of offsetting benefits affect individuals' acceptance of the conservation narrative. In Laikipia the social dynamics of land alienation, as well as perceptions about the limited realization of local returns from an external conservation agenda, may compound and significantly magnify responses to conflict and negative attitudes to wildlife (Dickman \& Hazzah, 2016).

Moreover, inaccuracies in the characterization of local impacts of human-wildlife conflict have implications for the scope of mitigation initiatives. Currently, local strategies for conflict management tend to focus on neighbouring agricultural areas with high levels of human-elephant conflict and crop raiding. The Laikipia Wildlife Forum's major conflict intervention project has involved the construction of a large-scale electric fence to protect smallholder farmers from crop-raiding elephants. Although this mitigates conflict in the wider area to some extent, this strategy does little to address conflict in pastoral areas. In the Mukogodo area the fence has been criticized for further marginalizing and alienating pastoral communities through reducing access to grazing areas (Evans \& Adams, 2016).

The high-resolution data from Makurian suggest that some forms of conflict are sufficiently widespread that targeted management interventions could have a broad impact.
There are already strategies in place for minimizing depredation losses in the area, including 'tightly bunched' grazing practices and the use of predator-proof metal and wire bomas, although their adoption has not been widespread, at least in part because of the challenges of regulating grazing (Hatfield, 2010) and the high costs of infrastructure (Frank, 2011). Compensation programmes for damage caused by wildlife have been widely critiqued but have demonstrated effectiveness in reducing retaliatory killings, and may function as a sustainable tool for distributing benefits from wildlife (Bauer et al., 2017). With a more thorough understanding of the locally specific experiences of conflict, adaptive interventions, including the potential creation of local compensation programmes, would be able to target local points of conflict more effectively.

To mitigate human-wildlife conflict, accurate, detailed and locally pertinent data on causes and consequences are required. Current monitoring, at least in Makurian, fails to represent the full scope of household conflict experiences. Although the data collected here are limited in spatial and temporal scope, they provide clear indicators of a broad range of conflicts experienced at one point in time. The answers to the four research questions make it clear that as livelihood opportunities and ecological conditions evolve, locally based, consistent, high-resolution monitoring of human-wildlife conflict will provide a more accurate understanding of the factors that will guide land use and livelihood choices at the local level, and conservation success at the regional level. With such information, strategic practices can be developed to reduce the incidence or severity of conflict (such as segregating land use), to mitigate unavoidable impacts (such as adapted husbandry practices or boma infrastructure) or to compensate effectively for residual consequences (such as accurate, timely and fair compensation schemes linked to tourism revenues).

As local expectations change and the rhetoric of sharing benefits from conservation spreads, local public opinion of costs and benefits must be addressed. Although contemporary stresses within traditional livelihoods may arise from a myriad factors beyond conservation, and may be exacerbated particularly by exclusions from former grazing lands now set aside for wildlife, by the perceived inequity of tourism benefits accrued by inhabitants of colonial-era ranches and by other land and livelihood issues affecting the region, there exists a strong interest in conservation as a means of meeting local livelihood expectations.

The challenge for those who are aware of the importance of conserving biodiversity is to ensure that the benefits of doing so are evident to those who live with the costs. Understanding those costs is therefore essential. Discussions are underway to introduce community-based monitoring with mobile phone technology to maintain ongoing, highresolution records of local human-wildlife conflict in Makurian. This could be an essential tool in determining 
the positive cost-benefit trade-off that will be required to improve or maintain good relations with nature at this site. Furthermore, success with such local involvement could help to advance the essential work of reimagining conservation and, more importantly, broaden the base of those committed to doing so.

\section{Acknowledgements}

This research was carried out with the permission of the Government of Kenya, through a partnership with the University of Nairobi, and with the assistance of Prof. Francis Mwaura. We are indebted to the Makurian community and all of the respondents who participated.

\section{Author contributions}

$\mathrm{AB}$ and $\mathrm{TM}$ collaborated on research design. $\mathrm{AB}$ led the fieldwork, primary data analysis and writing of the first draft of the article. TM made significant contributions to the implementation, analysis and write-up of this research.

\section{References}

Adams, W.M. (2003) Nature and the colonial mind. In Decolonizing Nature: Strategies for Conservation in a Post-colonial Era (eds W. M. Adams \& M. Mulligan), pp. 16-50. Earthscan, Abingdon, UK.

Adams, W.M. \& Hulme, D. (2001a) Conservation and community: changing narratives, policies and practices in African conservation. In African Wildlife \& Livelihoods (eds D. Hulme \& M. Murphree), pp. 9-23. James Curry, Oxford, UK.

Adams, W.M. \& Hulme, D. (2001b) If community conservation is the answer in Africa, what is the question? Oryx, 35, 193-200.

Adams, W.M. \& Sandbrook, C. (2013) Conservation, evidence and policy. Oryx, 47, 329-335.

Babrgir, S., Farhadinia, M.S. \& Moqanaki, E.M. (2017) Socio-economic consequences of cattle predation by the Endangered Persian leopard Panthera pardus saxicolor in a Caucasian conflict hotspot, northern Iran. Oryx, 51, 124-130.

Barrow, E. \& Fabricius, C. (2002) Do rural people really benefit from protected areas - rhetoric or reality? Parks, 12, 67-79.

Barua, M., Bhagwat, S.A. \& Jadhav, S. (2013) The hidden dimensions of human-wildlife conflict: health impacts, opportunity and transaction costs. Biological Conservation, 157, 309-316.

Bauer, H., Müller, L., Van Der Goes, D. \& Sillero-Zubiri, C. (2017) Financial compensation for damage to livestock by lions Panthera leo on community rangelands in Kenya. Oryx, 51, 106-114.

Bowen-Jones, E. (2012) Tackling Human-Wildlife Conflict: A Prerequisite for Linking Conservation and Poverty Alleviation: A Decision-Makers Guide to Financial and Institutional Mechanisms. IIED, London, UK.

Butynski, T.M. \& De Jong, Y.A. (2015) Laikipia County: Geography, Environment and Biodiversity. Unpublished report. Lolldaiga Hills Research Programme, Nanyuki, Kenya.

Craigie, I.D., Baillie, J.E.M., Balmford, A., Carbone, C., Collen, B., Green, R.E. \& Hutton, J.M. (2010) Large mammal population declines in Africa's protected areas. Biological Conservation, 143, 2221-2228.
Dickman, A.J. \& Hazzah, L. (2016) Money, myths and man-eaters: complexities of human-wildlife conflict. In Problematic Wildlife: A Cross-Disciplinary Approach (ed. F.M. Angelici), pp. 339-356. Springer International Publishing, Cham, Switzerland.

Evans, L.A. \& Adams, W.M. (2016) Fencing elephants: the hidden politics of wildlife fencing in Laikipia, Kenya. Land Use Policy, 51, 215-228.

Frank, L. (2011) Living with lions: lessons from Laikipia. Smithsonian Contributions to Zoology, 632, 73-83.

Frank, L.G., Woodroffe, R. \& Ogada, M.O. (2005) People and predators in Laikipia District, Kenya. In People and Wildlife: Conflict or Coexistence? (eds R. Woodroffe, S. Thirgood \& A. Rabinowitz), pp. 286-304. Cambridge University Press, Cambridge, UK.

HaCkel, J.D. (1999) Community conservation and the future of Africa's wildlife. Conservation Biology, 13, 726-734.

Hatfield, R. (2010) Consultant Report: Rangeland Rehabilitation and Management: July o9-Feb 10. Internal report. Laikipia Wildlife Forum, Laikipia, Kenya.

Hazzah, L., Dolrenry, S., Naughton-Treves, L., Edwards, C.T. T., Mwebi, O., Kearney, F. \& Frank, L. (2014) Efficacy of two lion conservation programs in Maasailand, Kenya. Conservation Biology, 28, 851-860.

Hemson, G., Maclennan, S., Mills, G., Johnson, P. \& MaCdonald, D. (2009) Community, lions, livestock and money: a spatial and social analysis of attitudes to wildlife and the conservation value of tourism in a human-carnivore conflict in Botswana. Biological Conservation, 142, 2718-2725.

Holmern, T., Nyahongo, J. \& Røskaft, E. (2007) Livestock loss caused by predators outside the Serengeti National Park, Tanzania. Biological Conservation, 135, 518-526.

Homewood, K.M., Chenevix Trench, P. \& Brockington, D. (2012) Pastoralist livelihoods and wildlife revenues in East Africa: a case for coexistence? Pastoralism: Research, Policy and Practice, https://doi.org/10.1186/2041-7136-2-19.

Hughes, R. \& Flintan, F. (2001) Integrating Conservation and Development Experience: A Review and Bibliography of the ICDP Literature. International Institute for Environment and Development, London, UK.

Jones, B.T.B., Davis, A., Diez, L. \& Diggle, R.W. (2013) Community-based natural resource management (CBNRM) and reducing poverty in Namibia. In Biodiversity Conservation and Poverty Alleviation: Exploring the Evidence for a Link (eds D. Roe, J. Elliott, C. Sandbrook \& M. Walpole), pp. 191-205.

Wiley-Blackwell, Oxford, UK.

Kenya National Bureau of Statistics (2010) The 2009 Kenya Population and Housing Census. Republic of Kenya, Nairobi, Kenya.

Khumalo, K.E. \& YUnG, L.A. (2015) Women, human-wildlife conflict, and CBNRM: hidden impacts and vulnerabilities in Kwandu Conservancy, Namibia. Conservation and Society, 13, 232-243.

Kinnaird, M.F. \& O'Brien, T.G. (2012) Effects of private-land use, livestock management, and human tolerance on diversity, distribution, and abundance of large African mammals. Conservation Biology, 26, 1026-1039.

KIRBY, K.R. (2014) "New conservation" as a moral imperative. Conservation Biology, 28, 639-640.

KIss, A. (2004) Is community-based ecotourism a good use of biodiversity conservation funds? Trends in Ecology \& Evolution, 19, 232-237.

Lamarque, F., Anderson, J., Fergusson, R., Lagrange, M., Osei-Owusu, Y. \& BAKker, L. (2009) Human-Wildlife Conflict in Africa: Causes, Consequences and Management Strategies. FAO 
Forestry Paper 157. Food and Agriculture Organization of the United Nations, Rome, Italy.

Leader-Williams, N., Adams, W.M. \& Smith, R.J. (2010) Deciding what to save: trade-offs in conservation. In Trade-offs in Conservation: Deciding What to Save (eds N. Leader-Williams, W.M. Adams \& R.J. Smith), pp. 3-14. Wiley-Blackwell, Oxford, UK.

Leisher, C., Sanjayan, M., Blockhus, J., Larsen, S.N. \& Kontoleon, A. (2013) Does conserving biodiversity work to reduce poverty? A state of knowledge review. In Biodiversity Conservation and Poverty Alleviation: Exploring the Evidence for a Link (eds D. Roe, J. Elliott, C. Sandbrook \& M. Walpole), pp. 15-159, Wiley-Blackwell, Oxford, UK.

Letai, J. \& Lind, J. (2013) Squeezed from all sides: changing resource tenure and pastoralist innovation on the Laikipia Plateau, Kenya. In Pastoralism and Development in Africa: Dynamic Change at the Margins (eds A. Catley, J. Lind \& I. Scoones), pp. 164-176, Routledge, New York, USA.

LWF (Laikipia Wildlife Forum) (2013) The Rural Economy of Laikipia as a Basis for a Model County. Internal Report, Laikipia Wildlife Forum, Nanyuki, Kenya.

LWF (Laikipia Wildlife Forum) (2016) Who we are. http://www. laikipia.org/about-us/ [accessed 11 April 2016].

McShane, T.O. \& Wells, M.P. (eds) (2004) Getting Biodiversity Projects to Work. Columbia University Press, New York, USA.

Naughton-Treves, L. \& Treves, A. (2005) Socio-ecological factors shaping local support for wildlife: crop-raiding by elephants and other wildlife in Africa. In People and Wildlife: Conflict or Coexistence? (eds R. Woodroffe, S. Thirgood \& A. Rabinowitz), pp. 252-277. Cambridge University Press, Cambridge, UK.

Newmark, W.D. \& Hough, J.L. (200o) Conserving wildlife in Africa: integrated conservation and development projects and beyond. BioScience, 50, 585-592.

OGADA, M.O. (2015) HWC $2003+10$ years: carnivore-livestock conflicts, tourism, donors, compensation: what about the human dimensions? Human Dimensions of Wildlife, 20, 329-332.

ONYANGO, P. (2014) Balancing of rights in land law: a key challenge in Kenya. Sociology and Anthropology, 2, 301-308.

Packer, C., Ikanda, D., Kissui, B. \& Kushnir, H. (2005) Conservation biology: lion attacks on humans in Tanzania. Nature, 436, 927-928.

Redpath, S.M., Bhatia, S. \& Young, J. (2015) Tilting at wildlife: reconsidering human-wildlife conflict. Oryx, 49, 222-225.

REID, R.S. (2013) Savannas of Our Birth: People, Wildlife and Change in East Africa. University of California Press, Berkeley, USA.

Roden, P., Bergmann, C., Ulrich, A. \& Nüsser, M. (2016) Tracing divergent livelihood pathways in the drylands: a perspective on two spatially proximate locations in Laikipia County, Kenya. Journal of Arid Environments, 124, 239-248.

Roe, D., Fancourt, M., Sandbrook, C., Sibanda, M., Giuliani, A. \& GORDON-MACLEAN, A. (2014) Which components or attributes of biodiversity influence which dimensions of poverty? Environmental Evidence, https://doi.org/10.1186/2047-2382-3-3.
Romañach, S.S., Lindsey, P.A. \& Woodroffe, R. (2007) Determinants of attitudes towards predators in central Kenya and suggestions for increasing tolerance in livestock dominated landscapes. Oryx, 41, 185-195.

Salerno, J., Borgerhoff Mulder, M., Grote, M.N., Ghiselli, M. \& PACKER, C. (2016) Household livelihoods and conflict with wildlife in community-based conservation areas across northern Tanzania. Oryx, 50, 702-712.

SAndBrook, C. (2015) What is conservation? Oryx, 49, 565-566.

Stolton, S., Dudley, N., Avcioğlu ÇokÇalişKan, B., Hunter, D., IvANIC, K.Z., KANGA, E. et al. (2015) Values and benefits of protected areas. In Protected Area Governance and Management (eds G.L. Worboys, M. Lockwood, A. Kothari, S. Feary \& I. Pulsford), pp. 145-168, ANU Press, Canberra, Australia.

Thirgood, S., Woodroffe, R. \& Rabinowitz, A. (2005) The impact of human-wildlife conflict on human lives and livelihoods. In People and Wildlife: Conflict or Coexistence? (eds R. Woodroffe, S. Thirgood \& A. Rabinowitz), pp. 13-26. Cambridge University Press, Cambridge, UK.

Ulrich, A., Speranza, C.I., Roden, P., Kiteme, B., Weismann, U. \& Nusser, M. (2012) Small-scale farming in semi-arid areas: livelihood dynamics between 1997 and 2010 in Laikipia, Kenya. Journal of Rural Studies, 28, 241-251.

Western, D., Russell, S. \& Cuthill, I. (2009) The status of wildlife in protected areas compared to non-protected areas of Kenya. PLoS ONE, 4(7), e6140.

Western, D. \& Waithaka, J. (2005) Policies for reducing humanwildlife conflict: a Kenya case study. In People and Wildlife: Conflict or Coexistence? (eds R. Woodroffe, S. Thirgood \& A. Rabinowitz), pp. 357-372. Cambridge University Press, Cambridge, UK.

Western, D., Waithaka, J. \& Kamanga, J. (2015) Finding space for wildlife beyond national parks and reducing conflict through community-based conservation: the Kenya experience. Parks, 21, 51-62.

Western, D. \& Wright, R.M. (1994) The background to community-based conservation. In Natural Connections: Perspectives in Community-Based Conservation (eds D. Western \& R.M. Wright), pp. 1-14. Island Press, Washington, D.C., USA.

\section{Biographical sketches}

Alec Blair has been working in Kenya since 2006, focusing on the engagement of local communities with conservation agendas. His research interests include the dynamics and challenges of livelihood diversification, the costs and benefits of ecotourism initiatives, and the interaction of international conservation interests with local decisionmaking. Thomas Meredith has been involved in community-based environmental conservation since 1970, and first visited Kenya in 1972. He has worked on conservation and development issues, environmental impact assessment, and public participation in environmental decision-making. 